Indian J. Fsychiat, 1998, 40 (1), 1-2

\title{
EDITORIAL
}

\section{RESEARCH JUSTICE}

Increasing interest in research in psychiatry has brought about a surge in the number of researches being conducted world wide which is reflected by the large number of research papers being deposited for publication in the ever increasing number of journals. Though increased interest in psychiatric research is encouraging but, unfortunately, this has led to pressure on researchers to carry on many projects simultaneously. This requires participation by other workers. The concept of 'participation' itself raises suspicion of an unequal relationship i.e. who participates on whose condition is not always clear. Interpretation by whom, about whom, with whom, for whom any why, are basic ethical questions in research co-operation.

'Dialogue' has the connotation of an equal relationship. but even the dialogue may be defined by the party who controls knowledge and resources (Mikkelsen, 1997). Multicenter trials are an example where the combined number of researchers from all centres may go to double figure and it becomes difficult for all of them to get their deserving share. This applies to the key researchers in any project only and the research assistants who actually carry out the project ultimately are the forgotten ones and only a lucky few get a place in 'et al., or acknowledgement.

This raises the basic issue of need for formulating code of ethics for research and making a central authority for monitoring and lodging grievances. Research nowadays is usually a team effort. Unless the team members coordinate their activities, the give and take of a group project can cause hurt feelings, frustration and an inferior quality research. Therefore it is necessary that before starting any research project, one must develop the group into a unit with a leader, develop a sense of effective collaboration and decide each persons role beforehand. The leader is not necessarily the most resourceful or knowledgeable person. Probably the best leader is the best "people person", the one who can smooth over the inevitable personality clashes, or the best manager, the one who can best conceptualize the stages of the project. Good leadership is a key ingredient in a group's success (Debs, 1991). Group members must understand how to collaborate effectively. Two key methods are goal sharing and deferring consensus (Bumett, 1991). Goal sharing means that individuals co-operate to achieve goals. Deferring consensus means that members agree to consider altematives and voice explicit disagreements. To manage the group's activities, the group must make a work plan that clarifies each person's assignments and deadlines (Pauley \& Riordan, 1996). Members should use a calendar to set the final due date and to discuss reasonable time frames for each stage in the process. The group should put everything in writing and should schedule regular meetings.

To clarify assignments and deadlines, the following questions should be answered before embarking on the project :

-What is the exact purpose of this research? - Must any sections be completed before others can be started?

-What is the dead line for each section? -What is the style sheet for the document? -What is each person's research and writing assignment?

-Who would be the authors of the final report and in which order? 
Guidelines by the International Committee of Medical Journal Editors state that all persons designated as authors should qualify for authorship. Each author should have participated sufficiently in the work to take public responsibility for the content. Authorship credit should be based only on substantial contributions to (1) conception and design, or analysis and interpretation of data, and to (2) drafting the article or revising it critically for important intellectuai content, and on (3) final approval of the version to be published. All the three conditions must be met. Participation solely in the acquisition of funding or the collection of data does not justify authorship. General supervision of the research group is not sufficient for authorship. Any part of an article critical to its main conclusions must be responsibility of at least one author. The order or authorship should be joint decision of the coauthors. In deciding on the order $r_{1}$ authors should be aware that many journals limit the number of authors. The US National Library of Medrcine (NLM) lists in MEDLINE only the first 24 plus the last author when there are more than 25 authors.

Finishang of a project requires two activities: editing and producing the final document. Groups can edit in several ways. They can edit as a group. or they can designate an editor. If they edit as a group, they can pass the sections around for comment, or they can meet to discuss the sections. Frankly, this method is cumbersome. Groups often over discuss smaller points and lose sight of larger issues. If the group designates one editor, that person can usuatly produce a consistent document. The editor should bring the edited document back to the group for review. Finally, the group must designate one member to oversee the final draft. This task takes time and requires close attention to detail.

There is a need to consider these suggestions so as to improve quality of research. to enhance cooperation in collaborative research and to encourage young researchers. One shouid be rewanded according to the efforts he puts in the work. This we can term as "research justice".

\section{J.K. Trivedi}

\section{REFERENCES}

Burnett, R.E. (1991) Substantive conflict in a cooperative conflict A way to improve the collaborative planning of a work place document. Technical Communication, 38 (4), 532-539.

Debs, M.B. (1991) Recent research on collaborative writing in industry. Technicaf Communication, 38 (4), 476-484.

Mikkeisen, B. (1997) interventions, Interpretations and Ethics. In : Methods for Development Work and Research, pp. 31-32, New Delhi : Sage Publications.

Pauley, S.E. \& Riordan, D.G. (1998) The technical writing process. In : Technical Report Writing Today, Edn. 5, pp, 18-50, Delhi: AlT8S Publishers 